\title{
EXTENSION OF ULTRADEPLETED MANTLE WITHIN THE CONTWOYTO TERRANE OF THE SLAVE CRATON, NORTHERN CANADA
}

\author{
Cookenboo HO
}

Distinct regions can be defined in the mantle beneath the Slave Craton, northern Canada, based on variations in Cr-pyrope chemistry. These regional mantle variations approximate intracratonic terrane boundaries and structural features defined from surface mapping, suggesting that mantle variation beneath the Slave Craton is long-lived, and may reflect the history of craton assembly. In the central Slave Craton, the Ekati and Diavik diamond mines, plus the advanced Snap Lake and Gaucho Kue (formerly 5034 and Kennady Lake) projects, all occur within the Contwoyto Terrane, which reportedly originated as a thick accretionary prism filled with turbidites overlying mafic volcanic strata, and is located east of the much older Anton Terrane (which was probably the source of the turbidites). Within the Contwoyto Terrane, kimberlites typically carry abundant sub-calcic (G10) Cr-pyrope garnets. Kimberlites typically carry few G10s in the Hackett River Terrane abutting the Contwoyto Terrane to the north. Within the Contwoyto Terrane, further mantle subdivisions seem possible based on garnet chemistry. The economic pipes of the Ekati and Diavik mines form two north-northeast trends closely paralleling Lac de Gras dyke sets. The Lac de Gras dykes extend from the Kilohigok basin in the north to approximately MacKay Lake in the south, within a restricted part of the Contwoyto Terrane. A distinctive suite of very sub-calcic Cr-pyropes ('G10s'), with $\mathrm{Cr} 2 \mathrm{O} 3$ between 5 and $11 \%$ have been reported for the Daivik pipes. Less Cr-rich (and less Ti-, Zr, and Y-depleted) G10s common to the Ekati pipes to the west are lacking in the Diavik pipes. South of Mackay Lake, Gl0s from Snap Lake include much more Cr-rich examples. Very sub-calcic Cr-pyropes have been recovered from till sampling programs north of MacKay Lake in the central Slave Craton, northern Canada. These very sub-calcic pyropes occur in distinct indicator dispersion trains with surface texture and distribution characteristics suggesting a proximal source to the east. However, the grains are chemically comparable to garnets from Diavik pipes $40 \mathrm{~km}$ to the north-northeast (across glacial transport directions). The Mackay Lake area sub-calcic Cr-pyropes contain between 5.5 and $10 \% \mathrm{Cr} 2 \mathrm{O} 3$, and as little as $1.8 \% \mathrm{CaO}$. Additionally, they are strongly depleted in titanium (mostly $<0.05 \% \mathrm{TiO} 2$ ). The till samples also lack Mg-ilmenite, and chrome diopside is rare, supporting derivation from $\mathrm{Ti}$ and $\mathrm{Ca}$ - depleted mantle. The garnet chemistry is closely comparable to the Cr-pyropes from the Diavik pipes, and thus may extend the shallow ultradepleted mantle layer south to Mackay Lake. The area from Diavik south to MacKay lake is dominated by supracrustal turbidites of the Yellowknife Supergroup. The apparent coincidence of the extents suggests a possible genetic link between the ultradepleted layer in the mantle and the turbidite basin. The depleted mantle may extend south from the Mackay Lake area to the Snap Lake and 5034 (Gaucho Kue) kimberlites, as evidenced by lack of Mg-ilmenite in 5034, and abundant aubcalcic Cr-pyropes in Snap Lake. However, the Snap Lake G10s are more Cr-rich than those from Diavik and Mackay Lake, suggesting a more complex mantle history. 